animal fibres to acquire a permanent set decreases with increasing time of heating with water and mercury at $80^{\circ} \mathrm{C}$.

\begin{tabular}{|c|c|c|c|c|c|}
\hline $\begin{array}{l}\text { Time of treatment } \\
\text { with water and } \\
\text { mercury at } 80^{\circ} \mathrm{C} \text {. }\end{array}$ & \multicolumn{5}{|c|}{$\begin{array}{l}\text { Percentage set after release in boiling water } \\
\text { for: }\end{array}$} \\
\hline Untreated & $40 \cdot 2$ & $24 \cdot 0$ & $22 \cdot 3$ & $22 \cdot 5$ & $22 \cdot 2$ \\
\hline 6 d. 2 hr. $15 \mathrm{~min}$. & $40 \cdot 4$ & $19 \cdot 0$ & $17 \cdot 6$ & $17 \cdot 4$ & $17 \cdot 1$ \\
\hline $8,, 23,, \quad 6$, & $40 \cdot 2$ & $15 \cdot 9$ & $15 \cdot 2$ & $14 \cdot 9$ & $14 \cdot 4$ \\
\hline $13 \cdot,, \quad 3,, 50$ & $40 \cdot 3$ & $12 \cdot 9$ & $12 \cdot 2$ & $12 \cdot 0$ & $11 \cdot 5$ \\
\hline $22,, 2,, 30 \quad$, & $40 \cdot 3$ & $2 \cdot 9$ & $-1 \cdot 6$ & $1 \cdot 1$ & 0.5 \\
\hline
\end{tabular}

In accordance with setting theory, too, the treated fibres showed an increased power of supercontraction in boiling 2 per cent borax solution. For example, fibres which had been treated for 22 days contracted 42 per cent after 40 minutes boiling, whereas the length of Antreated fibres remains unaltered under similar conditions. Contrary to Elöd's observations, therefore, supercontraction is promoted and set prevented when sulphur is removed from animal fibres by the combined action of water and mercury at $80^{\circ} \mathrm{C}$. The present conception of the chemical mechanism of permanent set ${ }^{3}$ remains valid, and the theoretical superstructure which Elöd has erected need not be discussed.

Textile Chemistry Laboratory,

J. B. Speakman.

University,

Leeds. June 30 .

${ }^{1}$ Speakman, J. B., Nature, 132, 930 (1933); Speakman, J. B., and Cooper, C. A., J. Text. Inst., 2\}, T 191 (1936).

8 Elōd, E., Nowotny, H., and Zahn, H., Koll. Z., 93, 50 (1940).

S Speakman, J. B., J. Soc. Dyers and Colourists, 52, 335 (1936); Speakman, J., B. Soc. Dyers and Whewell, C. S. Sibid,., 52, 380 (1936); Speakman, J. B., and Stoves, J. L., ibrid., 53, 236 (1937).

- Speakman, J. B., Stoves, J. L., and Bradbury, H., J. Sor. Dyers and Colo'trists, 57, 73 (1941).

\title{
Carcinogenic Agent without the Condensed Carbon Ring Structure
}

IN an earlier publication ${ }^{1}$ the formula of the highly active synthetic œstrogenic analogue, stilbœstrol, was contrasted with those of cestrone and chrysene. The figures in this earlier letter in NaturE indicated that by ring closure in the case of stilbœstrol a condensed carbon ring compound similar to œstrone on one hand and to chrysene on the other could be obtained. Since all the known carcinogenic hydrocarbons possess the condensed carbon ring structure, it was decided, by analogy with œstrone, to see if it were possible to break down the condensed ring structure of the carcinogenic hydrocarbons without losing all carcinogenic activity.

Two groups of twenty-five adult stock male mice, one group of coloured, the other of albino mice, have been painted twice weekly with a 0.3 per cent solution of $\alpha$-ethyl- $\beta$-sec-butylstilbene in benzene. Fig. 1 indicates how this substance can be derived from either benzpyrene or dimethylchrysene by fissure of the rings.<smiles></smiles>

BENZPY RENE

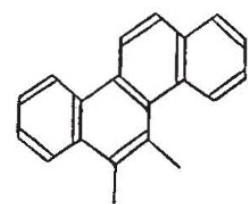

DIMEThylCh RYSENe Fig. 1.

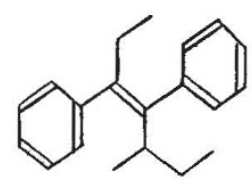

$\alpha$-EтнYL- $\beta$-secBUTYLSTILBENE
Two tumours have developed in these groups. One of the seven coloured mice (CM 160/40) surviving after 12 months painting, had a tumour on the edge of the painted region at the back of the neck. It grew. more rapidly than was expected, reaching a size of $2 \mathrm{~cm} . \times 2 \mathrm{~cm}$., and became necrotic. A second tumour was found in one of the thirteen albino mice $(C M$ 44/40) surviving after 15 months painting. This was a slow-growing tumour situated subcutaneously on the rump $2 \mathrm{~cm}$. distant from the painted area. At autopsy it was hard and $1.5 \mathrm{~cm} . \times$ $\mathrm{C} .5 \mathrm{~cm}$. in size. In neither case were any metastases found.

Histologically, the two tumours were very similar (see Fig. 2), being spindle-celled and malignant. The first one was a spindle-celled carcinoma, the second a sarcoma. Attempts to transplant the first were unsuccessful, but fragments of the sarcoma were implanted in ten stock albino mice and, at the time of writing, two months after implantation, tumours have developed in five of the ten. The largest tumour $(2 \mathrm{~cm} . \times 1 \mathrm{~cm}$.) has been sectioned and proved to be similar to the parent sarcoma.

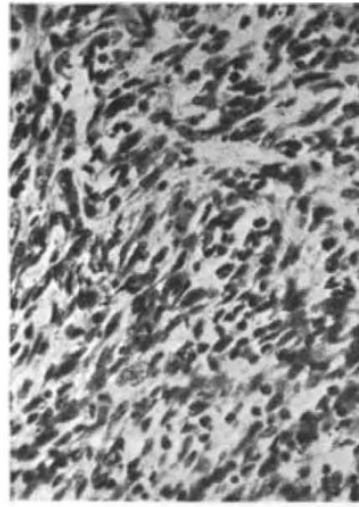

CM $160 / 40(\times 200)$

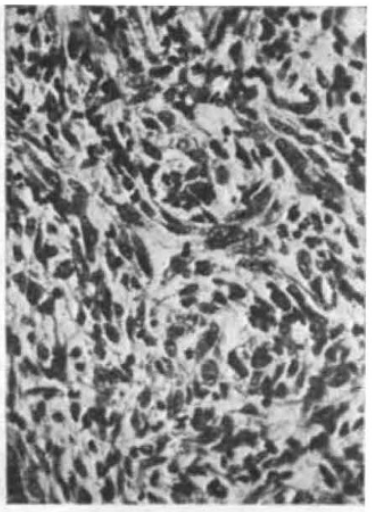

CM 44/40 (×250)
Fig. 2 .

A further group of fifty mice is now being painted with the same compound in an attempt to confirm the results, and other chemically related compounds are being investigated. If the results are confirmed, we believe that this is the first instance of carcinogenesis associated with painting a hydrocarbon without a condensed ring structure.

No positive results have been obtained by painting mice with diphenylhexane, diphenylhexadiene or diethylstilbene for shorter periods (6-9 months) in the same way; and no tumours were found on painting groups of twenty-five coloured mice twice weekly with $0 \cdot 3$ per cent acetone solution of $4: 4^{\prime}$. dihydroxy- $\alpha \beta$-diethylstilbene (stilbœstrol), 4 : 4' -dihydroxydiphenylhexane (hexœstrol) or 4:4'-dihydroxystilbene for similar short periods. Stilbœstrol when given by this method was unexpectedly toxic, and none of the mice survived for more than three months.

E. C. Donds.

W. LAWSON.

P. C. Williams*.

Courtauld Institute of Biochemistry,

Middlesex Hospital Medical School,

London, W.1.

* Beit Memorial Research Fellow.

${ }^{1}$ Dodds, E. C., Golberg, L., Lawson, W., and Robinson, R., NATURE, 141, 247 (1938). 